\title{
Analisis Transmisi Harga Beras di Kabupaten Ogan Komering Ilir Provinsi Sumatera Selatan
}

\author{
Price Transmission Analysis of Rice in Ogan Komering Ilir District, \\ South Sumatra Province \\ Endang Lastinawati ${ }^{1 *}$, Andy Mulyana ${ }^{2}$, Imron Zahri ${ }^{2}$, dan Sriati Sriati ${ }^{2}$ \\ ${ }^{1}$ Fakultas Pertanian Universitas Baturaja, Sumatera Selatan 32115 \\ ${ }^{2}$ Fakultas Pertanian Universitas Sriwijaya, Indralaya, Sumatera Selatan 30862 \\ ${ }^{*}$ Penulis untuk korespondensi: endang.lastinawati@gmail.com
}

\begin{abstract}
Price transmission is one indicator of whether or not a marketing system is efficient and also can explain the distribution of welfare between producers and consumers in the marketing channel. This study aimed to analyze the transmission of rice prices which are the basic needs of the Indonesian people, both the price transmission of consumer to farmers, and vice versa, with two groups of rice based on their quality, namely premium and medium rice. This research conducted at Ogan Komering Ilir District, South Sumatra Province. Price transmission was analyzed using price transmission elasticity, using weekly rice price series data from the second week of March 2016 to the second week of September 2018. The results showed that the transmission of consumer prices of premium and medium rice to the price of harvested dry grain at farmer level had an elasticity value not equal to one, and vice versa. This shows that the rice market in Ogan Komering Ilir Regency was in elastic and less efficient, because prices were transmitted asymmetrically.
\end{abstract}

Keywords: premium and medium rice, price transmission

\begin{abstract}
ABSTRAK
Transmisi harga merupakan salah satu indikator efisien atau tidaknya suatu sistem pemasaran, sekaligus dapat menjelaskan distribusi kesejahteraan antara produsen dan konsumen dalam saluran pemasaran. Penelitian ini bertujuan menganalisis transmisi harga beras yang merupakan kebutuhan dasar masyarakat Indonesia, baik transmisi harga konsumen terhadap petani, maupun sebaliknya, dengan dua kelompok beras berdasarkan kualitasnya yaitu beras premium dan medium. Penelitian ini dilaksanakan di Kabupaten Ogan Komering Ilir Provinsi Sumatera Selatan. Transmisi harga dianalisis menggunakan elastisitas transmisi harga, menggunakan data runtut waktu harga beras mingguan sejak minggu kedua Maret 2016 hingga minggu kedua September 2018. Hasil penelitian menunjukkan bahwa transmisi harga beras premium dan medium tingkat konsumen terhadap harga gabah kering panen tingkat petani memiliki nilai elastisitas tidak sama dengan satu. Demikian pula sebaliknya. Ini menunjukkan bahwa pasar beras di Kabupaten Ogan Komering Ilir bersifat in elastis dan kurang efisien, karena harga ditransmisikan secara asimetris.
\end{abstract}

Kata kunci: beras premium dan medium, transmisi harga 


\section{PENDAHULUAN}

Beras adalah kebutuhan dasar masyarakat Indonesia dan merupakan komoditas utama yang dihasilkan oleh petani pada umumnya. Kebutuhan beras di Indonesia mengalami peningkatan lebih dari 30 juta ton per tahun. Rata-rata pertumbuhan populasi dan tingkat konsumsi beras masih relatif tinggi. Oleh karena itu, peningkatan produksi beras untuk memenuhi kecukupan pangan merupakan tujuan penting yang hendak dicapai pemerintah. Beberapa kebijakan telah ditetapkan pemerintah untuk pengembangan usahatani padi dalam rangka meningkatkan produktivitas dan produksi beras di dalam negeri (Rasyid et al. 2016; Alam dan Effendy 2017).

Sumatera Selatan merupakan salah satu lumbung pangan nasional, dengan produksi padi sawah 4.106.495 ton dan padi ladang 141.427 ton pada tahun 2015. Dari tiga belas kabupaten dan empat kota di Provinsi Sumatera Selatan, Kabupaten Ogan Komering Ilir (OKI) merupakan sentra produksi padi ketiga setelah Kabupaten Banyuasin dan Kabupaten Ogan Komering Ulu Timur (OKUT). Pada tahun 2015, Kabupaten OKI menghasilkan padi sawah 612.706 ton atau $14,40 \%$ dan padi ladang 11.311 ton atau $0,27 \%$ dari total produksi padi di Provinsi Sumatera Selatan (BPS 2016).

Luas lahan baku sawah pada tahun 2017 di Kabupaten OKI mencapai 188.328 hektar yang tersebar di delapan belas kecamatan, dan 5.650 hektar (3\%) sudah menggunakan irigasi, yaitu di Kecamatan Lempuing (BPS 2018). Agroekosistem sawah di Kabupaten OKI umumnya berupa lahan rawa lebak. Menurut Kodir et al. (2016), Kabupaten OKI dan Ogan Ilir (OI) merupakan daerah di Sumatera Selatan dengan lahan rawa lebak paling luas dan berpotensi, yaitu mencapai 59.150 hektar.

Harga suatu komoditas adalah faktor yang sangat penting dalam ekonomi pasar karena mengkoordinasikan keputusan produsen dan konsumen dalam berperilaku di bawah kondisi yang bersaing sempurna (Brummer et al. 2009). Setiap harga yang terbentuk seharusnya dapat memuaskan semua pelaku pasar, baik petani, pedagang, maupun konsumen (Rahmi dan Arif 2012).

Fenomena transmisi harga telah menarik perhatian banyak peneliti di beberapa pasar komoditas. Dalam beberapa tahun terakhir, banyak penelitian dilakukan untuk menganalisis hubungan antara petani, pedagang grosir, dan pasar eceran. Fokus utama dari penelitian tersebut berorientasi pada estimasi elastisitas dan kecepatan price shock ditransmisikan pada level yang berbeda dalam rantai pemasaran (Kharin 2015).

Penelitian ini bertujuan menganalisis transmisi harga vertikal beras premium dan medium di Kabupaten OKI sebagai salah satu daerah sentra produksi padi dengan agroekosistem rawa lebak yang potensial di Provinsi Sumatera Selatan. Penelitian tentang elastisitas transmisi harga merupakan hal yang penting dilakukan karena berguna bagi pengambil kebijakan dalam mengukur distribusi kesejahteraan antara produsen dan konsumen sekaligus sebagai indikator efisiensi harga dalam suatu saluran pemasaran. Harga yang ditransmisikan secara asimetris dapat menyebabkan petani yang umumnya menjadi pihak yang mengalami kerugian, akan selalu hidup dalam garis kemiskinan (Drabik et al. 2016). Penelitian ini bertujuan menganalisis transmisi harga beras yang merupakan kebutuhan dasar masyarakat Indonesia, baik transmisi harga konsumen terhadap petani, maupun sebaliknya, dengan dua kelompok beras berdasarkan kualitasnya yaitu beras premium dan medium.

\section{BAHAN DAN METODE}

\section{Tempat dan Waktu}

Penelitian dilakukan dengan menetapkan Kabupaten OKI secara purposive sebagai lokasi penelitian. Kabupaten OKI dipilih karena merupakan salah satu sentra produksi padi di Provinsi 
Sumatera Selatan yang memiliki agroekosistem rawa lebak yang sangat potensial untuk pengembangan usahatani padi. Penelitian dilakukan sejak bulan Mei 2018 hingga September 2018.

\section{Metode Penelitian}

Penelitian ini dilakukan dengan menggunakan metode historis. Metode ini digunakan karena untuk menganalisis elastisitas transmisi harga beras, peneliti harus mengumpulkan berbagai informasi terkait data harga beras dari waktu ke waktu di masa lalu dan masa sekarang, untuk menjelaskan kondisi harga beras saat ini maupun memprediksi kondisi di masa yang akan datang.

\section{Analisis Data}

Penelitian ini menggunakan data sekunder berupa data runtut waktu harga eceran beras premium dan medium di Kabupaten OKI setiap minggu, mulai minggu kedua bulan Maret 2016 hingga minggu kedua bulan September 2018 yang diperoleh dari Sistem Informasi Panel Harga Badan Ketahanan Pangan.

Transmisi harga beras di Kabupaten OKI diukur dengan menggunakan elastisitas transmisi harga yang secara matematis dirumuskan sebagai berikut :

$$
\begin{aligned}
& E t=\frac{\partial \operatorname{Pr} / \operatorname{Pr}}{\partial P f / P f} \\
& E t=\frac{\partial \operatorname{Pr}}{\partial P f} \cdot \frac{P f}{\operatorname{Pr}}
\end{aligned}
$$

Harga memiliki hubungan linier di mana Pf merupakan fungsi dari Pr dengan rumus matematis sebagai berikut :

$$
\mathrm{Pf}=\mathrm{a}+\mathrm{bPr}
$$

Dari persamaan (2) diperoleh :

$$
\frac{\partial P f}{\partial \operatorname{Pr}}=b
$$

atau

$$
\frac{\partial \operatorname{Pr}}{\partial P f}=\frac{1}{b}
$$

Sehingga $E t=\frac{1}{b} \cdot \frac{P f}{\operatorname{Pr}}$

Keterangan:

$\delta \mathrm{Pf}=$ perubahan harga gabah kering panen (GKP) di tingkat petani

$\delta \mathrm{Pr}=$ perubahan harga beras di tingkat konsumen

$\mathrm{Pf}=$ harga rata-rata GKP di tingkat petani

$\operatorname{Pr}=$ harga rata-rata beras di tingkat konsumen

$\mathrm{b}=$ koefisien regesi persamaan

Dengan kriteria menurut Hasyim dalam Prayitno et al. (2013) :

Jika Et = 1, maka (1) laju perubahan harga di tingkat petani sama dengan laju perubahan harga di tingkat konsumen; (2) pasar yang berlaku adalah pasar bersaing sempurna; (3) sistem pemasaran sudah efisien.

Jika Et $<1$, maka (1) laju perubahan harga di tingkat petani lebih kecil daripada laju perubahan harga di tingkat konsumen; (2) pasar yang berlaku adalah pasar bersaing tidak sempurna; (3) sistem pemasaran belum efisien.

Jika Et > 1, maka (1) laju perubahan harga di tingkat petani lebih besar daripada laju perubahan harga di tingkat konsumen; (2) pasar yang berlaku adalah pasar tidak bersaing sempurna; (3) sistem pemasaran belum efisien.

\section{HASIL}

Grafik harga eceran beras premium, medium dan GKP di Kabupaten OKI (Gambar 1) menunjukkan bahwa harga eceran beras di tingkat konsumen untuk 
beras premium dan beras medium, maupun harga GKP di tingkat petani di Kabupaten OKI mengalami fluktuasi sepanjang tahun 2016 hingga 2018. Kenaikan harga terjadi pada akhir tahun karena terjadi kelangkaan pasokan beras karena belum masuk masa panen. Tetapi mulai bulan Maret, harga beras dan GKP kembali turun karena petani sudah panen raya, dan selanjutnya secara umum harga beras dan GKP di Kabupaten OKI stabil sepanjang tahun.

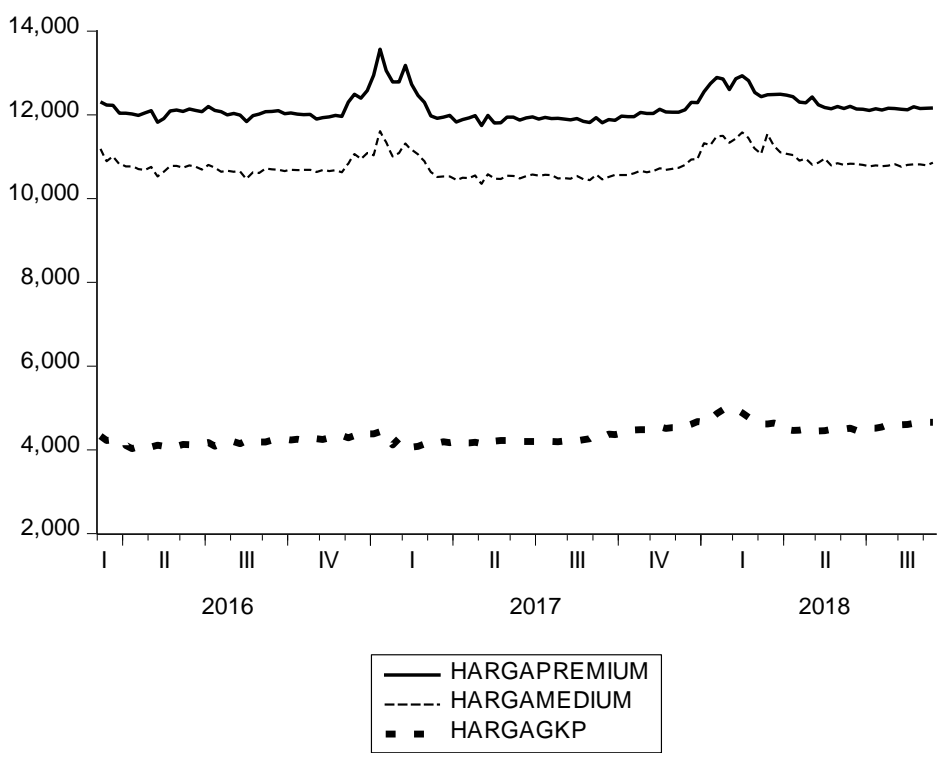

Gambar 1. Perkembangan harga beras premium, medium dan GKP di Kabupaten OKI

Dari grafik harga terlihat bahwa pergerakan harga eceran beras di tingkat konsumen memiliki arah yang sama dengan pergerakan harga GKP di tingkat petani, tetapi disparitas harga antara konsumen dan petani cukup besar.

Artinya, harga yang diterima petani saat menjual gabahnya memiliki selisih yang besar dengan harga yang dibayarkan konsumen untuk membeli beras.

\section{Elastisitas Transmisi Harga Beras Premium di Kabupaten OKI}

Regresi linear sederhana harga beras premium di tingkat konsumen terhadap harga GKP di tingkat petani di Kabupaten OKI menghasilkan persamaan sebagai berikut:

$$
\mathrm{Pf}=381,18+0,326 \operatorname{Pr}_{\text {premium }}
$$

Berdasarkan hasil analisis data sekunder, rata-rata harga GKP di tingkat petani adalah $\mathrm{Rp} 4.344,67$ dan rata-rata harga beras premium di tingkat konsumen adalah Rp12.171,97. Dengan demikian, elastisitas transmisi harga beras premium di tingkat konsumen terhadap harga GKP di tingkat petani adalah :

$$
\begin{aligned}
E t & =\frac{1}{b} \cdot \frac{P f}{\operatorname{Pr}} \\
& =3,068 \cdot 0,357 \\
& =1,095
\end{aligned}
$$

Perhitungan elastisitas transmisi harga menunjukkan nilai Et $>1$. Artinya, setiap kenaikan harga beras premium di tingkat konsumen sebesar $1 \%$ akan menaikkan harga GKP di tingkat petani sebesar 1,095. Nilai elastisitas transmisi harga yang lebih dari satu juga menunjukkan bahwa sistem pasar belum efisien dan tidak bersaing sempurna.

Sedangkan regresi linear sederhana harga GKP di tingkat petani terhadap harga beras premium di tingkat konsumen di Kabupaten OKI menghasilkan persamaan sebagai berikut:

$$
\operatorname{Pr}_{\text {premium }}=9146,68+0,696 \mathrm{Pf}
$$


Dengan nilai elastisitas transmisi harga sebagai berikut:

$$
\begin{aligned}
E t & =b \cdot \frac{P f}{\operatorname{Pr}} \\
& =0,696 \cdot 0,357 \\
& =0,249
\end{aligned}
$$

Nilai elastisitas transmisi harga GKP di tingkat petani terhadap harga beras premium di tingkat konsumen sebesar 0,249 (Et < 1). Ini berarti laju perubahan harga di tingkat konsumen lebih kecil daripada laju perubahan harga di tingkat petani, karena jika harga GKP di tingkat petani naik 1\%, akan menyebabkan harga beras premium di tingkat konsumen mengalami kenaikan hanya sebesar 0,249.

\section{Elastisitas Transmisi Harga Beras Medium di Kabupaten OKI}

Regresi linear sederhana harga beras medium di tingkat konsumen terhadap harga GKP di tingkat petani di Kabupaten OKI menghasilkan persamaan :

$$
\mathrm{Pf}=-747,85+0,472 \mathrm{Pr}_{\text {medium }}
$$

Rata-rata harga beras medium di Kabupaten OKI adalah Rp10.791,84. Sehingga transmisi harga beras medium di tingkat konsumen terhadap harga GKP di tingkat petani memiliki nilai elastisitas sebagai berikut :

$$
\begin{aligned}
E t & =\frac{1}{b} \cdot \frac{P f}{\operatorname{Pr}} \\
& =2,119 \cdot 0,403 \\
& =0,854
\end{aligned}
$$

Regresi linear sederhana harga GKP di tingkat petani terhadap harga beras medium di tingkat konsumen di Kabupaten OKI dinyatakan dalam persamaan sebagai berikut:

$$
\operatorname{Pr}_{\text {medium }}=7541,15+0,748 \mathrm{Pf}
$$

Nilai elastisitas transmisi harga GKP di tingkat petani terhadap harga beras medium di tingkat konsumen sebagai berikut:

$$
E t=b \cdot \frac{P f}{\operatorname{Pr}}
$$

$$
\begin{aligned}
& =0,748 \cdot 0,403 \\
& =0,301
\end{aligned}
$$

Elastisitas transmisi harga beras medium di tingkat konsumen terhadap harga GKP di tingkat petani maupun sebaliknya memiliki nilai yang kurang dari satu $($ Et < 1). Elastisitas transmisi harga beras medium terhadap GKP sebesar 0,854 bermakna bahwa setiap kenaikan $1 \%$ harga beras medium di tingkat konsumen akan menaikkan harga GKP di tingkat petani sebesar 0,854. Artinya, laju perubahan harga di tingkat petani lebih kecil daripada laju perubahan harga di tingkat konsumen, atau terjadi transmisi harga yang tidak simetris.

Demikian juga dengan transmisi harga GKP di tingkat petani terhadap harga beras medium di tingkat konsumen dengan nilai elastisitas sebesar 0,301 bermakna bahwa apabila harga GKP di tingkat petani naik $1 \%$, maka harga beras medium di tingkat konsumen juga mengalami kenaikan sebesar 0,301. Ternyata untuk beras medium, laju perubahan harga beras di tingkat konsumen akibat perubahan harga GKP di tingkat petani masih lebih kecil dibandingkan laju perubahan GKP di tingkat produsen akibat perubahan harga beras di tingkat konsumen $(0,301<0,854)$. Maka dapat disimpulkan secara umum, bahwa di Kabupaten OKI, perubahan harga GKP di tingkat produsen lebih peka dibandingkan perubahan harga di tingkat konsumen, karena laju perubahan harga di tingkat produsen lebih tinggi dibandingkan laju perubahan harga di tingkat konsumen, baik untuk beras premium maupun medium.

\section{PEMBAHASAN}

Menurut Yustiningsih (2012), di Indonesia dalam jangka pendek transmisi harga gabah kering panen petani terhadap harga beras konsumen bersifat simetris. Sedangkan dalam jangka panjang bersifat asimetris.

Sejalan dengan itu, penelitian Swastika dan Sumaryanto (2012) juga 
menyatakan bahwa pasar beras umumnya tidak simetris, di mana kenaikan harga beras di tingkat konsumen tidak menyebabkan harga gabah di tingkat petani ikut naik. Sebaliknya jika harga beras di tingkat konsumen turun, menyebabkan harga gabah di tingkat petani ikut turun. Di Kabupaten Karawang Jawa Barat, hubungan harga antara petani dan pedagang adalah asimetris, di mana petani memperoleh keuntungan bersih yang lebih rendah dibandingkan pedagang (Widyarini, et al. 016).

Tetapi di Kabupaten OKI justru laju perubahan harga di tingkat petani lebih tinggi daripada laju perubahan harga di tingkat konsumen. Artinya, perubahan harga yang disebabkan oleh naik turunnya harga beras di tingkat konsumen lebih peka direspon oleh petani, yang ditunjukkan oleh nilai elastisitas transmisi harga tingkat petani yang lebih tinggi dibandingkan elastisitas transmisi harga di tingkat konsumen. Hal ini diduga dipengaruhi akibat adanya penetapan Harga Eceran Tertinggi (HET) beras oleh pemerintah. Sejak tanggal 1 September 2017, pemerintah menetapkan HET beras dengan nilai yang berbeda-beda berdasarkan wilayah penjualannya, yaitu $\mathrm{Rp} 12.800,00$ untuk beras premium dan Rp9.450,00 untuk beras medium di wilayah Sumatera Selatan. Akibat penetapan HET beras, pedagang tidak boleh menjual berasnya melebihi HET yang ditetapkan. Inilah yang membuat kepekaan perubahan harga di tingkat konsumen lebih kecil dibandingkan kepekaan perubahan harga di tingkat produsen.

Kondisi sebaliknya terjadi di sisi produsen. Akibat adanya penggolongan HET berdasarkan kualitas beras premium dan medium, maka produsen akan berusaha untuk menghasilkan beras premium dengan HET yang lebih tinggi. Akibatnya beberapa bulan setelah penetapan HET sempat terjadi kelangkaan beras medium, bahkan hingga saat ini harganya masih melampaui HET karena diduga kurangnya stok beras medium. Oleh sebab itu, elastisitas transmisi harga beras medium lebih kecil dan lebih lambat laju perubahannya dibandingkan elastisitas beras premium.

Masalah transmisi harga yang tidak simetris perlu dicarikan solusi oleh pemerintah. Transmisi harga yang tidak simetris mengindikasikan adanya penyalahgunaan market power oleh pedagang perantara yang terlibat dalam rantai pemasaran, atau bahkan disebabkan oleh adanya kebijakan pemerintah itu sendiri. Oleh karena itu, sistem pemasaran yang tidak efisien harus dibenahi, agar tidak terjadi disparitas harga yang lebar antara produsen dengan konsumen. Sehingga pendapatan dan kesejahteraan antara produsen-konsumen dapat terdistribusi secara merata.

\section{KESIMPULAN}

Transmisi harga beras premium dan medium antara konsumen terhadap petani maupun antara petani terhadap konsumen di Kabupaten OKI terjadi secara asimetri, karena nilai elastisitas transmisi harga yang tidak sama dengan satu $(\mathrm{Et} \neq 1)$. Kondisi ini juga menjadi indikator bahwa sistem pemasaran beras di Kabupaten OKI belum efisien.

\section{UCAPAN TERIMA KASIH}

Ucapan terima kasih dan penghargaan disampaikan pada LPDP selaku penyandang dana dalam penelitian dengan kontrak nomor: PRJ5915/LPDP.3/2016.

\section{DAFTAR PUSTAKA}

Alam MN and Effendy. 2017. Identifying Factors Influencing Production and Rice Farming Income with Approach of Path Analysis. American Journal of Agricultural and Biological Sciences 12(1): 3943. 
PS. 2016. Data Series Sumatera Selatan 2016. Sumatera Selatan: Badan Pusat Statistik.

BPS. 2018. Kabupaten Ogan Komering Ilir dalam Angka 2018. OKI: Badan Pusat Statistik.

Brummer B, Taubadel SC, dan Zorya S. 2009. The Impact of Market and Policy Instability on Price Transmission between Wheat and Flour in Ukraine. European Review of Agricultural Economics 36(2):203-230.

Drabik D, Ciaian P, dan Pokrivcak J. 2016. The Effect of Ethanol Policies on the Vertical Price Transmission in Corn and Food Markets. Energy Economics 55: 189-199.

Kharin S. 2015. Vertical Price Transmission along the Diary Supply Chain in Russia. Studies in Agricultural Economics 117: 80-85.

Kodir KA, Juwita Y, dan Arif T. 2016. Inventarisasi dan Karakteristik Morfologi Padi Lokal Lahan Rawa di Sumatera Selatan. Buletin Plasma Nutfah 22(2):101-108.

Prayitno AB, Hasyim AI, dan Situmorang S. 2013. Efisiensi Pemasaran Cabai Merah di Kecamatan Adiluwih Kabupaten Pringsewu Provinsi Lampung. JIIA 1(1):53-59.
Rahmi E dan Arif B. 2012. Analisis Transmisi Harga Jagung sebagai Bahan Pakan Ternak Ayam Ras di Sumatera Barat. Jurnal Peternakan Indonesia 14(2): 343-348.

Rasyid MN, Setiawan B, Mustadjab MM, and Hanani N. 2016. Factors that Influence Rice Production and Technical Efficiency in the Context of an Integrated Crop Management Field School Program. American Journal of Applied Sciences 13(11):1201-1204.

Swastika DKS dan Sumaryanto. 2012. Rantai Pasok Beras di Indonesia (Kasus Provinsi Jabar, Kalbar, dan Kalsel) dalam Lokollo, E.M. Bunga Rampai Rantai Pasok Komoditas Pertanian Indonesia. Bogor: IPB Press 11-43.

Widyarini M, Simatupang TM, dan Engelseth P. 2016. Social Interaction and Price Transmission in Multi-Tier Food Supply Chains. Journal of Operations and Supply Chain Management 9(1):110-128.

Yustiningsih F. 2012. Analisa Integrasi Pasar dan Transmisi Harga Beras Petani-Konsumen di Indonesia. Tesis. Jakarta: Fakultas Ekonomi Universitas Indonesia. 